\title{
The Study of Thermal Conversion \\ of Mechanically Activated Aspen Wood in the Presence of High-Silica Zeolite Catalyst
}

\author{
Victor I. Sharypov*a,b, Natalia G. Beregovtsova ${ }^{a}$, \\ Sergei V. Baryshnikov ${ }^{a}$, Anatoly M. Zhyzhaeva, \\ Alexander V. Vosmerikov ${ }^{\mathrm{c}}$ and Boris N. Kuznetsov ${ }^{\mathrm{a}, \mathrm{b}}$ \\ a Institute of Chemistry and Chemical Technology SB RAS \\ 50-24 Akademgorodok, Krasnoyarsk, 660036, Russia \\ ${ }^{b}$ Siberian Federal University \\ 79 Svobodny, Krasnoyarsk, 660041, Russia \\ ${ }^{c}$ Institute of Petroleum Chemistry SB RAS \\ 4 Akademichesky Av., Tomsk, 634021, Russia
}

Received 04.04.2015, received in revised form 21.05.2015, accepted 06.06.2015

The influence of zeolite catalysts in the H-form with silicate module 60 (HSZ-60) and mechanochemical treatment in the activator mill AGO-2 on the thermal conversion of aspen wood has been studied.

It was found that the joint mechanochemical activation of aspen wood and HSZ-60 catalyst results in a drastic decrease in particles size of the mixture components in destruction of the main structural components of wood and increases the homogenity of zeolite catalyst distribution on the wood surface and the degree of aspen wood conversion in supercritical ethanol. Catalyst HSZ-60 increases by 1,6-2,2 times the yield of ethanol soluble products with boiling point up to $180{ }^{\circ} \mathrm{C}$ and promotes the etherification reactions of acids, obtained during degradation of wood components.

Keywords: aspen-wood, high-silica zeolite catalyst, mechanochemical activation, thermal conversions, supercritical ethanol, liquid hydrocarbons, composition.

DOI: $10.17516 / 1998-2836-2015-8-2-190-201$.

(C) Siberian Federal University. All rights reserved

* Corresponding author E-mail address: sharypov@icct.ru 


\title{
Изучение термического превращения механохимически активи- рованной древесины осины в присутствии высококремнеземно-
}

\section{го цеолитного катализатора}

\author{
В.И. Шарыпов ${ }^{\text {a, }}$, Н.Г. Береговцова ${ }^{a}$, С.В. Барышников ${ }^{\text {, }}$ \\ А.М. Жижаев ${ }^{\text {a }, ~ А . В . ~ В о с м е р и к о в ~}{ }^{\text {, Б.Н. Кузнецов }}{ }^{\text {a, }}$ \\ ${ }^{a}$ Институт химии и химической технологии СО РАН \\ Россия, 660036, Красноярск, Академгородок 50, стр. 24 \\ ${ }^{\sigma}$ Сибирский федеральный университет \\ Россия, 660041, Красноярск, пр. Свободный, 79 \\ ${ }^{\circ}$ Институт химии нефти СО РАН \\ Россия, 634021, Томск, пр. Академический, 4
}

Исследовано влияние добавок высококремнеземного цчеолита в Н-форме с силикатным модулем 60 (НВКЦ-60) и механохимической обработки древесины осины в мельнице-активаторе АГО-2 на ее термические превращцения.

Установлено, что совместное механохимическое активирование древесинь осинь и катализатора НВКЦ-60 приводит крезкому уменьшению размера частиц компонентов смеси, разрушению основных структурных компонентов древесины, дисперсному распределению катализатора по поверхности древесины и к увеличению степени конверсии древесины осины в процессе термопревращчения в среде сверхкритического этанола. В присутствии катализатора НВКЦ-60 происходит увеличение выхода этанолрастворимых продуктов, выкипающих до $180{ }^{\circ} \mathrm{C}$, в 1,6-2,2 раза и промотирование реакциии этерификации кислот, образующихся при деструкциии компонентов древесины.

Ключевые слова: древесина осины, цеолитный катализатор, механохимическое активирование, термические превращчения, сверхкритический этанол, жидкие углеводороды, состав.

\section{Введение}

Биомасса является наиболее перспективным сырьем, альтернативным нефти и природному газу, для производства химических продуктов и жидких топлив. В последнее десятилетие Европейский союз принял ряд программ развития энергетики, согласно которым к 2020 г. планируется до 30 \% топлив получать из возобновляемых источников [1].

Для получения химических веществ из биомассы необходимо провести деполимеризацию макромолекул основных ее компонентов (целлюлозы, гемицеллюлоз и лигнина) и трансформировать образующиеся продукты для придания им требуемых свойств.

Эффективная деструкция биомассы может быть осуществлена термическими методами. Пиролиз древесины без доступа кислорода приводит к образованию газообразных продуктов, обуглероженного остатка, воды и смол пиролиза. Выход последних достигает в зависимости от типа сырья 20-27 мас. \% при 400 С. Смолы пиролиза в значительном количестве представле- 
ны полифенолами и полиароматическими углеводородами, что затрудняет их использование в качестве сырья для производства жидких топлив [2].

Повышенный выход легкокипящих продуктов может быть достигнут в процессе термопревращения древесины в среде органических растворителей, находящихся в сверхкритических условиях [3]. Особый интерес представляет использование в качестве суперкритических флюидов низших алифатических спиртов, поскольку они характеризуются относительно невысокими значениями критических параметров (температуры и давления) и способны стабилизировать продукты термопревращения путем их алкилирования. Показана возможность регулирования состава продуктов за счет использования катализаторов, в том числе твердых катализаторов кислотного типа [4-7].

Ранее нами было проведено исследование термоконверсии в среде до- и сверхкритического этанола древесины осины, обработанной в мехактиваторе АГО-2 в этаноле. Было показано, что увеличение рабочего давления с 4,0 до 22,0 МПа сопровождается ростом степени превращения с 67 до 90 \% и выхода продуктов растворения в этаноле с 55 до 76 мас. \% при температуре процесса $350{ }^{\circ} \mathrm{C}[8]$.

Целью настоящего исследования являлось изучение влияния катализатора на основе высококремнеземного цеолита в Н-форме с силикатным модулем 60 на термические превращения механохимически активированной древесины осины.

\section{Экспериментальная часть}

В работе использовали древесину осины, содержащую ( \% в расчете на массу абсолютно сухой древесины): 46,3 - целлюлозы; 20,4 - лигнина; 24,1 - гемицеллюлоз; 3,5 - водорастворимых веществ; 5,2 - экстрактивных веществ; 0,5 - золы. Древесину измельчали до размеров частиц менее 1 мм и высушивали при $100{ }^{\circ} \mathrm{C}$ до влажности менее 1 мас. \%. В качестве катализатора использовали высококремнеземный цеолит в Н-форме (НВКЦ-60) с мольным отношением $\mathrm{SiO}_{2} / \mathrm{Al}_{2} \mathrm{O}_{3}=60$, синтезированный в лабораторных условиях в ИХН СО РАН. Его удельная поверхность составляла 276 м$^{2} /$, объем пор 0,11 см$^{3} /$ г. Катализатор добавляли к древесине в количестве 10 мас. \%. Древесину и её смесь с катализатором подвергали механической обработке в энергонапряженной мельнице-активаторе АГО-2 в сухом виде в течение 30 мин при ускорении, развиваемом мелящими телами $60 \mathrm{~g}$.

Исходная древесина и образцы после механической обработки исследовали с использованием сканирующего микроскопа SEM TM-3000 «Hitachi».

Термические свойства образцов древесины исследовали методом ТГА на приборе «Netzsch STA 449F1» в температурном интервале от 30 до $900{ }^{\circ} \mathrm{C}$ при скорости нагрева образца $10^{\circ} \mathrm{C} / \mathrm{Mnн}^{\circ}$ в потоке аргона. Загрузка образца составляла $\approx 6$ мг, использовали корундовый тигель.

Термическое превращение древесины в среде этанола проводили во вращающемся автоклаве ёмкостью 0,25 л. В автоклав помещали 5 г древесины или ее смесь с цеолитным катализатором в зависимости от условий эксперимента, количество загружаемого этанола составляло 15 мл. Сосуд автоклава закрывали, продували аргоном для удаления воздуха и нагревали до $350{ }^{\circ} \mathrm{C}$. Данное значение температуры было выбрано по результатам исследования древесины осины термогравиметрическим методом и примерно соответствует основному максимуму потери массы на дифференциальной кривой. Продолжительность эксперимента составляла 60 
мин. Рабочее давление в автоклаве изменялось в интервале 7,0-9,2 МПа в зависимости от добавок катализатора и способов его введения.

После завершения процесса продукты превращения количественно извлекали из автоклава вымыванием этанолом и последовательно экстрагировали этанолом и водой. Далее из экстрактов отгоняли растворитель без кипения, остаток высушивали под вакуумом до постоянного веса и определяли его выход. Выход продуктов, выкипающих до $180{ }^{\circ} \mathrm{C}$, определяли по разности: 100 мас. \% - (выход водорастворимых продуктов + выход этанолрастворимых продуктов, кипящих выше $180^{\circ} \mathrm{C}+$ выход газообразных продуктов).

Аликвотную часть жидких продуктов анализировали методом хромато-массспектрометрии (GC-MS) с использованием хроматографа Agilent 7890A, снабженного детектором селективных масс Agilent 7000A Triple Quad при регистрации полного ионного тока. Разделение продуктов осуществляли на капиллярной колонке HP-5MS длиной 30 м с внутренним диаметром 0,25 мм при программировании температуры в интервале $40-250{ }^{\circ} \mathrm{C}$ (скорость подъема температуры $3{ }^{\circ} \mathrm{C} /$ мин).

Содержание сахаров в водорастворимых продуктах после синтеза их триметилсилильных (TMC) эфиров устанавливали методом ГЖХ с использованием хроматографа «VARIAN-450 $\mathrm{GC»}$ с пламенно-ионизационном детектором по методике $[9,10]$. В качестве силирующего реагента брали смесь триметилхлорсилана и гексаметилдисилазана в среде пиридина, а в качестве внутреннего стандарта - сорбит. Использовалась капиллярная колонка VF - 624ms длиной 30 м, с внутренним диаметром 0,32 мм. Условия хроматографирования: газ-носитель - гелий, температура инжектора $250^{\circ} \mathrm{C}$, начальная температура колонки $50{ }^{\circ} \mathrm{C}$, подъем температуры до $180{ }^{\circ} \mathrm{C}$ со скоростью $10^{\circ} \mathrm{C} /$ мин, выдержка при $180{ }^{\circ} \mathrm{C}$. Температура детектора $280{ }^{\circ} \mathrm{C}$. Продолжительность хроматографического разделения 55 мин.

\section{Результаты и обсуждение}

В процессе активирования древесины осины в мельнице-активаторе АГО-2 в выбранных условиях происходит резкое уменьшение размера частиц и значительное изменение в структуре древесного вещества. Наблюдается фибрилляция пучков волокон, разрыв и деформация волокон либриформа и трахеид, значительное разрушение и деформация стенок крупных сосудов. Совместное активирование с цеолитным катализатором, кроме отмеченных выше закономерностей, приводит к уменьшению размеров частиц катализатора и их закреплению на поверхности древесины, вероятно, в результате механического вдавливания под воздействием мелящих тел (рис. 1).

По данным ТГА на дифференциальной кривой термического превращения древесины осины наблюдается основной пик потери массы при $363{ }^{\circ} \mathrm{C}$ и плечо в области $250-310{ }^{\circ} \mathrm{C}$ (рис. 2). Наличие последнего обычно связывают с термическим превращением гемицеллюлоз [11, 12]. Механохимическое активирование древесины осины и ее механохимическая обработка совместно с цеолитным катализатором приводят к смещению пика основной потери массы в область низких температур на 15 и $25^{\circ} \mathrm{C}$, соответственно (табл. 1).

В процессе термического превращения древесины в среде сверхкритического этанола ее предварительное механохимическое активирование в АГО-2 влечет за собой заметное увеличение степени конверсии древесины (рис. 3). Ранее аналогичный эффект был получен при

$$
-193-
$$



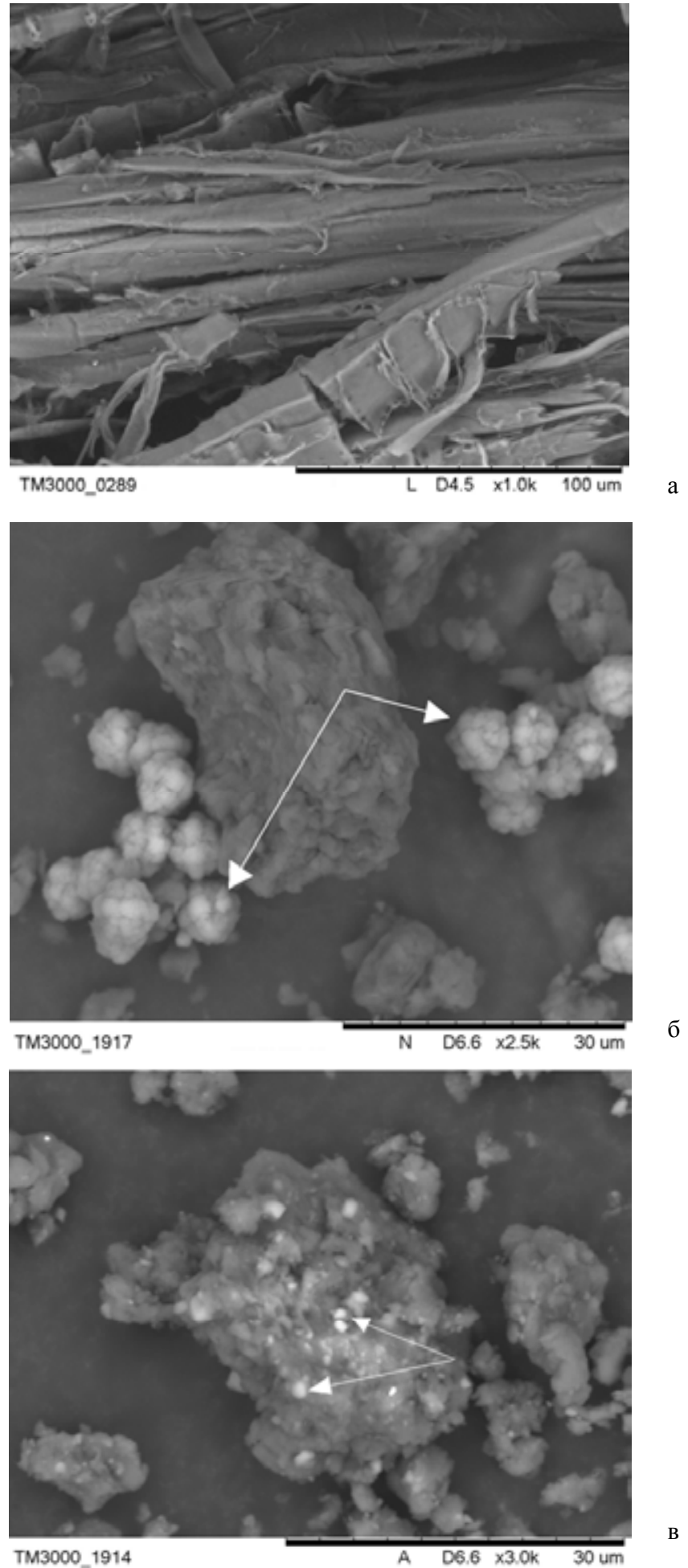

Рис. 1. Электронно-микроскопические снимки образцов древесины осины: а - исходный образец; б - образец после активирования в АГО-2, смешанный с катализатором НВКЦ-60; в - образец после совместного активирования в АГО-2 с катализатором НВКЦ-60. Стрелками отмечены частицы катализатора 


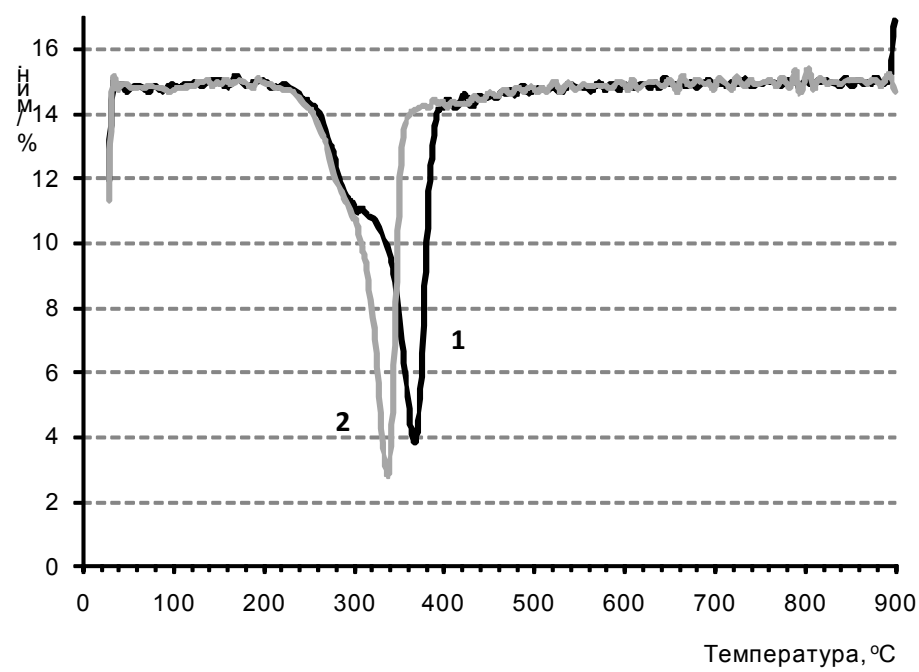

Рис. 2. Дифференциальные кривые потери массы образцов исходной древесины (1) и древесины, подвергнутой активированию в АГО-2 в смеси с НВКЦ - 60 (2)

Таблица 1. Данные термогравиметрических исследований

\begin{tabular}{|c|c|c|c|c|}
\hline \multirow[t]{2}{*}{ Образец } & \multicolumn{3}{|c|}{$\begin{array}{c}\text { Температурный интервал } \\
\text { пика основного термического } \\
\text { разложения, }{ }^{\circ} \mathrm{C}\end{array}$} & \multirow{2}{*}{$\begin{array}{c}\text { Потеря органической массы при } \\
\text { температуре завершения основного } \\
\text { термического разложения, \% }\end{array}$} \\
\hline & $\mathrm{T}_{\text {начала }}$ & $\mathrm{T}_{\text {max }}$ & $\mathrm{T}_{\text {завершения }}$ & \\
\hline Исходная древесины & 246 & 363 & 383 & 69 \\
\hline $\begin{array}{l}\text { Древесина, активированная в } \\
\text { АГО-2 }\end{array}$ & 246 & 348 & 378 & 69 \\
\hline $\begin{array}{l}\text { Древесина + НВКЦ-60, } \\
\text { активированные в АГО-2 }\end{array}$ & 246 & 338 & 358 & 70 \\
\hline
\end{tabular}

активировании древесины осины в АГО-2 в среде этанола [8]. Добавка цеолитного катализатора не увеличивает степень конверсии древесины, однако способствует существенному увеличению выхода фракции жидких продуктов, выкипающих до $180{ }^{\circ} \mathrm{C}$, за счет снижения выхода фракции этанолрастворимых продуктов, кипящих выше $180{ }^{\circ} \mathrm{C}$, и водорастворимых продуктов. Наблюдаемый эффект выше при использовании совместного активирования катализатора НВКЦ-60 и древесины. В этом случае выход легкокипящей фракции увеличивается более чем в 2 раза по сравнению с опытом без катализатора. Отмеченная закономерность может быть связана как с более дисперсным распределением катализатора НВКЦ-60 по поверхности частиц древесины, так и с изменением текстурных характеристик и кислотных свойств цеолитного катализатора в процессе его обработки в энергонапряженных мельницахактиваторах [13].

Исследование этанолрастворимых продуктов методом хромато-масс-спектрометрии показало, что они состоят из углеводородов, образующихся из этанола, древесины и продуктов взаимодействия древесных продуктов с этанолом (рис. 4). Состав продуктов превращения 


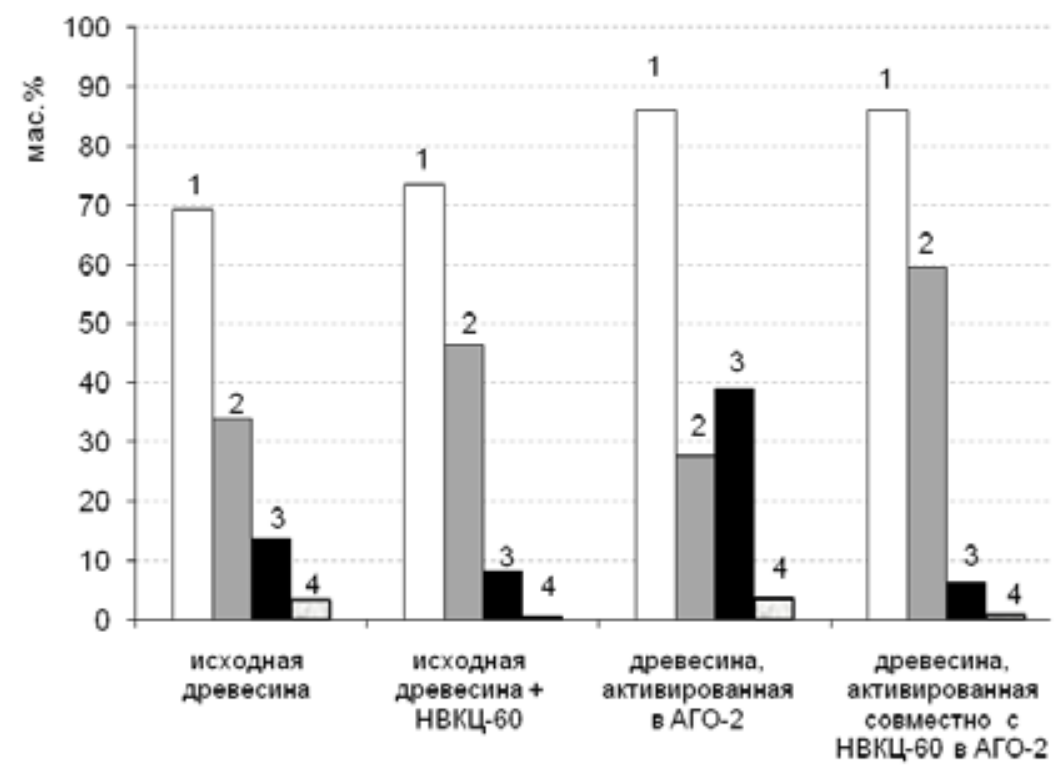

Рис. 3. Влияние мехактивирования и добавок катализатора НВКЦ-60 на степень превращения (1) и выход продуктов термического превращения древесины осины в этаноле при $350{ }^{\circ} \mathrm{C}: 2$ - этанолрастворимые продукты с Ткип. $<180{ }^{\circ} \mathrm{C} ; 3$ - этанолрастворимые продукты с Ткип. $>180{ }^{\circ} \mathrm{C} ; 4$ - водорастворимые продукты

сверхкритического этанола при $350{ }^{\circ} \mathrm{C}$ был исследован нами ранее [14] и в настоящей статье не обсуждается. Из табл. 2 следует, что под воздействием добавок цеолитного катализатора в составе продуктов увеличивается число этиловых эфиров оксикислот и насыщенных жирных кислот. Вероятно, образование эфиров является одной из причин увеличения выхода легкокипящих продуктов в процессе термопревращения активированной древесины осины в присутствии НВКЦ-60 (рис. 3). Образование этиловых эфиров в результате реакций этерификации соответствующих кислот в присутствии цеолита H-ZSM - 5, протекающих в процессе термопревращения биомасла, полученного из древесины бука, в среде этанола отмечено в работе [15]. Этиловые эфиры оксикислот и жирных кислот, в том числе этиловый эфир н-гексадекановой кислоты, были обнаружены в составе продуктов экстракции бука сверхкритическим этанолом [16]. О присутствии жирных кислот, таких как пальмитиновая кислота (н-гексадекановой кислота) и линолевая кислота ((Z,Z)-9,12-октадекадиенова кислота) в продуктах ожижения биомассы, сообщалось в работах $[17,18]$.

По данным ГЖХ, состав водорастворимых продуктов на 60-70 \% от их массы представлен ксилозой и глюкозой, которые, очевидно, образуются в процессе гидролиза целлюлозы.

\section{Выводы}

1. Установлено, что совместное механохимическое активирование в сухом виде древесины осины и высококремнеземного цеолитного катализатора в Н-форме с силикатным модулем 60 (НВКЦ-60) приводит к резкому уменьшению размера частиц компонентов смеси, разрушению основных структурных компонентов древесины и дисперсному распределению цеолита по поверхности древесины, что проявляется в смещении 


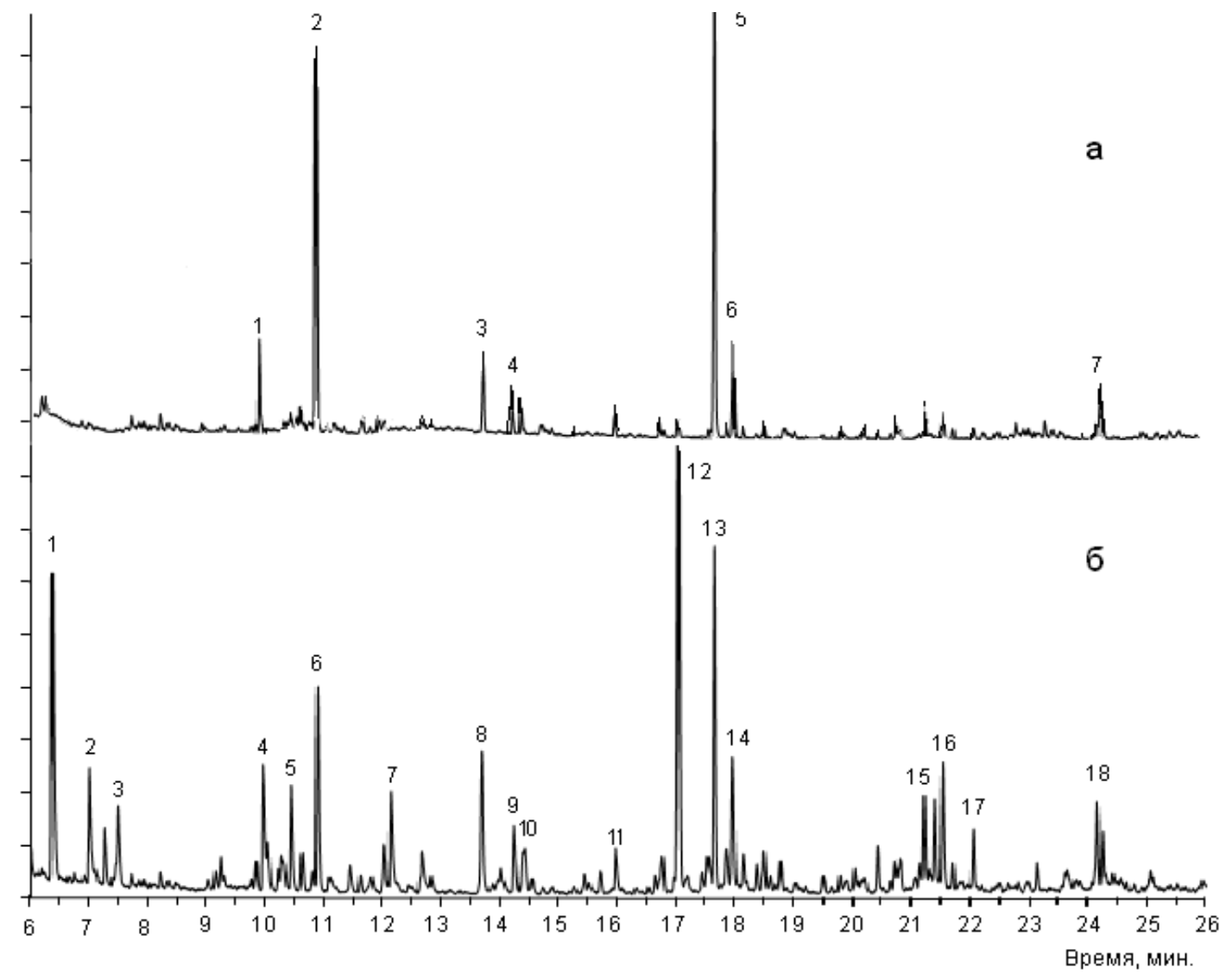

Рис. 4. Фрагмент хроматограмм: а) продуктов термопревращения древесины осины при $350{ }^{\circ} \mathrm{C}$ в сверхкритическом этаноле: 1 - 2-метил-2-циклопентен -1-он; 2 - 1-(1-этоксиэтокси)-гексен -3; 3 - фенол; 4 - 2,3-диметил-2-циклопентен-1-он; 5 - ангидрид 2-метилпропановой кислоты; 6 - 2-метоксифенол; 7 - 4- этил-2-метоксифенол; б) продуктов термопревращения активированной смеси древесины осины и катализатора НВКЦ-60 при $350{ }^{\circ} \mathrm{C}$ в сверхкритическом этаноле: 1 - этиловый эфир 2-гидроксипропановой кислоты; 2-2-циклопентен-1-он; 3 - этиловый эфир 2-бутеновой кислоты; 4-2-метил-2-циклопентен-1-он; 5 -этиловый эфир этоксиуксусной кислоты; 6-1-(1-этоксиэтокси)-гексен -3; 7 - 5-метилдигидрофуранон 2; 8 - фенол; 9 - 2,3-диметил-2-циклопентен-1-он; 10 - этиловый эфир 3-гидрокси-2,2-диметил бутановой кислоты; 11 - 2,3-диметил-2-циклопентен-1-он; 12 - этиловый эфир 4-оксипентановой кислоты; 13 ангидрид 2-метилпропановой кислоты; 14 - 2-метоксифенол; 15 - диэтиловый эфир бутандиовой кислоты; 16 - 4-метил-2-метоксифенол; 17 - диэтиловый эфир метилбутандиовой кислоты; 18 - 4- этил2-метоксифенол 
Таблица 2. Вещественный состав жидких продуктов превращения древесины осины при $350{ }^{\circ} \mathrm{C}$ без катализатора (1) и в присутствии НВКЦ-60 (2)

\begin{tabular}{|c|c|c|c|}
\hline \multirow{2}{*}{$\begin{array}{c}\text { Время } \\
\text { выхода, мин }\end{array}$} & \multirow{2}{*}{ Соединение } & \multicolumn{2}{|c|}{ Содержание, \%** } \\
\hline & & 1 & 2 \\
\hline 1 & 2 & 3 & 4 \\
\hline 5,9 & Этиловый эфир бутановой кислоты & - & 5,9 \\
\hline 6,4 & Этиловый эфир 2-гидрокси пропановой кислоты* & - & 6,3 \\
\hline 6,9 & 2-циклопентен-1-он* & - & 2,7 \\
\hline 7,3 & 2-гидроксициклопентен-2-ен,1-он & - & 1 \\
\hline 5 & Этиловый эфир 2- бутеновой кислоты & - & 2,2 \\
\hline 9,1 & 1-(2-фуранил)-1-пропанон & - & 0,4 \\
\hline 9,2 & 4-пентеновая кислота & - & 0,6 \\
\hline 9,8 & Этиловый эфир пентановой кислоты & - & 0,5 \\
\hline 9,9 & 2-метил-2-циклопентен-1-он & 3,6 & 2,8 \\
\hline 10,0 & Этиловый эфир 2-гидрокси-бутановой кислоты* & - & 1,1 \\
\hline 10,3 & 4-гидрокси-бутановая кислота & - & 1,1 \\
\hline 10,4 & Этиловый эфир этоксиуксусной кислоты & - & 2,2 \\
\hline 10,8 & Этиловый эфир 4-пентеновой кислоты & - & 1,2 \\
\hline 10,9 & 1-(1-этоксиэтокси)-гексен -3 & 22 & 4 \\
\hline 11,4 & 1-циклогексилэтанол & - & 0,7 \\
\hline 11,6 & Этиловый эфир 2-метил-2- бутеновой кислоты & - & 0,4 \\
\hline 12,0 & Этиловый эфир-2-пентеновой кислоты & - & 1,2 \\
\hline 12,1 & 5-метилдигидрофуранон-2 & - & 2 \\
\hline 12,7 & 2- метил-2-циклопентен-1-он & - & 0,9 \\
\hline 13,7 & Фенол* & 4,3 & 3,4 \\
\hline 14,2 & 2,3-диметил-2-циклопентен-1-он* & 1,3 & 1,4 \\
\hline 14,4 & 2-метил-2-этоксипропан & 1,1 & - \\
\hline 14,4 & Этиловый эфир 3-гидрокси-2,2-диметил бутановой кислоты & - & 1,7 \\
\hline 15,4 & 3,4,4-триметил-2-циклопентен-1-он & - & 0,3 \\
\hline 15,9 & 2,3- диметил-2-циклопентен-1-он & 1,1 & 0,9 \\
\hline 16,6 & Этиловый эфир 2-фуранкарбоновой кислоты* & - & 0,4 \\
\hline 16,8 & 3-метилфенол & 0,8 & 0,9 \\
\hline 17,0 & Этиловый эфир 4-оксипентановой кислоты* & 1 & 8,8 \\
\hline 17,5 & 4-метилфенол & - & 0,8 \\
\hline 17,6 & Ангидрид 2-метилпропановой кислоты & 29,6 & 6,7 \\
\hline 17,8 & 2-этил гексановая кислота & 0,4 & 0,9 \\
\hline 17,9 & 2-метоксифенол* & 3,9 & 2,8 \\
\hline 18,1 & Этиловый эфир 2-метил-4-оксипентановой кислоты & 0,3 & 0,6 \\
\hline 18,5 & Не идентифицировано & - & 0,9 \\
\hline 18,8 & 1,2,3-триметил-2-циклопентен-1-карбоновая кислота & - & 0,5 \\
\hline 20,0 & 5-метил-2-фуранметанол & - & 0,4 \\
\hline 20,7 & 4-этилфенол & 0,7 & - \\
\hline 20,8 & Этиловый эфир бензойной кислоты & 0,8 & - \\
\hline 21,2 & Диэтиловый эфир бутандиовой кислоты* & 1,3 & 1,3 \\
\hline
\end{tabular}


Продолжение табл. 2.

\begin{tabular}{|l|l|l|l|}
\hline \multicolumn{1}{|c|}{1} & \multicolumn{1}{|c|}{2} & \multicolumn{1}{|c|}{3} & \multicolumn{1}{|c|}{4} \\
\hline 21,4 & Этил 2-этил-3-гидроксивалериат & - & 1,3 \\
\hline 21,5 & 4-метил-2-метокси-фенол & 1,5 & 2,5 \\
\hline 21,7 & Этиловый эфир октановой кислоты & 0,5 & 0,4 \\
\hline 22,1 & Диэтиловый эфир метил-бутандиовой кислоты & 0,5 & 1 \\
\hline 24,2 & 4-этил-2-метокси-фенол & 1,8 & 1,7 \\
\hline 24,3 & Диэтиловый эфир пентандиовой кислоты & 0,3 & 0,9 \\
\hline 26,2 & 2,6-диметоксифенол* & 2,9 & 5,1 \\
\hline 26,4 & 2,4-диметоксифенол & - & 0,3 \\
\hline 26,6 & 2-метокси-4-пропилфенол* & 4,7 & 2,1 \\
\hline 28,7 & 1,2,4-триметокси* & 2,2 & 4,7 \\
\hline 30,7 & 5-терт-бутилпирогаллол* & 1,8 & 2,2 \\
\hline 30,9 & 5-н-бутилпирогаллол & 0,2 & 0,3 \\
\hline 32,7 & 4-пропил-1,1'-дифенил & 5,3 & 3,9 \\
\hline 34,4 & Этиловый эфир (2-окси-циклопентинил-4-бутановой кислоты) & 1,4 & 1,9 \\
\hline 40,8 & Этиловый эфир гексадекановой кислоты* & 4,6 & 1,9 \\
\hline
\end{tabular}

* Соединения, обнаруженные в составе продуктов экстракции бука сверхкритическим этанолом [16]. ** \% от суммы площадей всех пиков.

основного пика дифференциальной кривой потери массы на $25^{\circ} \mathrm{C}$ в низкотемпературную область и к изменению формы кривой.

2. Механохимическое активирование приводит к увеличению степени конверсии древесины осины в процессе ее термопревращения в среде сверхкритического этанола при $350{ }^{\circ} \mathrm{C}$. Установлен компонентный состав этанолрастворимых продуктов. Добавки катализатора НВКЦ-60 увеличивают выход легкокипящей фракции этанолрастворимых продуктов в 1,6-2,2 раза и промотируют реакции этерификации кислот, образующихся при деструкции компонентов древесины.

\section{Список литературы}

1. http://eur-lex.europa.eu/legal-content/EN/TXT/?uri=CELEX:32009L0028

2. Heitner C., Dimmel D., Schmidt J. Lignin and Lignans: Advances in Chemistry. CRC Press. 2010. $683 \mathrm{p}$.

3. Боголицын К.Г. Перспективы применения сверхкритических флюидных технологий в химии растительного сырья. Сверхкритические флюиды: теория и практика. 2007. Т.2(1). C.16-27. [Bogolitsyn K.G. Prospects for the use of supercritical fluid technology in chemistry plant raw materials. Supercritical fluids: theory and practice. 2007. T.2(1). C.16-27. (In Russ.)].

4. Guisnet M., Gilson J.-P. Zeolites for Cleaner Technologies. London: Imperial College Press, 2002. $378 \mathrm{p}$.

5. Larabi C., Maksoud W., Szeto K.C., Roubaud A., Castelli P., C. Santini C., Walter. J.J. Thermal decomposition of lignocellulosic biomass in the presence of Catalysts. Bioresource Technology. 2013. V.148. P. 255-260. 
6. Larabi C., Maksoud W., Szeto K.C., Garrona A., Arquillierea P.P., Waltera J.J., Santini C.C. Multifunctional heterogeneous catalyst for one step transformation of lignocellulosic biomass into low oxygenated hydrocarbons // Applied Catalysis A: General. 2015. V. 495. P. 162-172.

7. Кузнецов Б.Н., Чесноков Н.В., Яценкова О.В., Шарыпов В.И. Новые гетерогеннокаталитические методы конверсии лигноцеллюлозной биомассы в химические продукты // Известия Академии наук. Серия химическая. 2013. № 7, C.1493-1503. [Kuznetsov B.N., Chesnokov N.V., Yatsenkova O.V. et. al. The new heterogeneous-catalytic methods of lignocellulosic biomass conversion to chemical products. Russian Chemical Bulletin. 2013. № 7. C.1493-1503. (In Russ.)]

8. Барышников С.В., Шарыпов В.И., Береговцова Н.Г., Таран О.П., Агабеков В.Е., Кузнецов Б.Н. Термическое растворение механоактивированной древесины осины в среде до и сверхкритического этанола // Журнал Сиб. федер. ун-та. Химия. 2014. Т.7(3). С.455-465. (Baryshnikov S.V., Sharypov V.I., Beregovtsova N.G. et.al. Thermal Conversion of Mechanically Activated Aspen Wood in Sub - and Supercritical Ethanol Medium. J. of Siberian Federal University. Chemistry. 2014. T.7(3). C.455-465. (In Russ.)]

9. Оболенская А.В. Лабораторные работы по химии древесины и целлюлозы. М.: Экология, 1991. 152 с. [Obolenskaya A.V. Laboratory work on the chemistry of wood and cellulose. М .: Ecology, 1991. 152 p. (In Russ.)]

10. Ruiz-Matute A.I., Hernandez-Hernandez O., Rodriguez-Sanchez S., Sanz M.L., MartinezCastro I. Derivatization of carbohydrates for GC and GC-MS analyses // J. Chromatogr. B. 2011. V. 879. P. 1226-1240.

11. Poletto M., Zattera A.J., Forte M.M.C., Santana R.M.C.. Thermal decomposition of wood: Influence of wood components and cellulose crystallite size // Bioresource Technology. 2012. V.109. P.148-153.

12. Кислицын А.Н. Пиролиз древесины: химизм, кинетика, продукты, новые процессы. М.: Лесн. пром-сть, 1990. 312 с. [Kislitsyn A.N. Pyrolysis of wood: chemistry, kinetics, products, new processes. M .: Forest prom., 1990. 312 p. (In Russ.)]

13. Восмериков А.В., Величкина Л.М., Восмерикова Л.И., Коробицина Л.Л., Иванов Г.В. Применение механохимических технологий в цеолитном катализе // Химия в интересах устойчивого развития. 2002. V.10. C.45-51. [Vosmerikov A.V., Velichkina L.M., Vosmerikov L.I. et.al. Application of Mechanochemical Technologies in Zeolite Catalysis. Chemistry for sustainable development. 2002. V.10. C.45-51. (In Russ.)]

14. Береговцова Н.Г., Шарыпов В.И., Барышников С.В., Гришечко Л.И., Восьмериков А.В., Кузнецов Б.Н. Конверсия этанола при 350 и $400{ }^{\circ} \mathrm{C}$ в присутствии цеолитных катализаторов с различным силикатным модулем // Журнал Сиб. федер. ун-та. Химия. 2014. Т. 7(2). С. 242-251. [Beregovtsova N.G., Sharypov V.I., Baryshnikov S.V. et.al. Conversion of Ethanol at 350 and $400{ }^{\circ} \mathrm{C}$ in the Presence of Zeolite Catalysts with Different Si/Al Ratio. J. of Siberian Federal University. Chemistry. 2014. T. 7(2). C. 242-251. (In Russ.)]

15. Peng J., Chen P., Lou H., Zheng X. Catalytic upgrading of bio-oil by HZSM-5 in sub- and supercritical ethanol // Bioresource Technology. 2009. V. 100. P. 3415-3418. 
16. Akalın M.R., Karagöza S., Akyüzb Me. Supercritical ethanol extraction of bio-oils from German beech wood: Design of experiments Industrial // Crops and Products. 2013. V. 49. P. 720729.

17. Akalin M.K., Tekin K., Karagoz S. Hydrothermal liquefaction of cornelian cherry stones for bio-oil production // Bioresour. Technol. 2012. V. 110. P. 682-687.

18. Karagoz S., Bhaskar T., Muto A., Sakata Y., Uddin Md.A.. Low-temperature hydrothermal treatment of biomass: effect of reaction parameters on products and boiling point distributions. Energy Fuels. 2000. V. 418. P. 234-241. 